\title{
Culture, Corporate Governance and Analysts Forecast in Malaysia
}

\author{
Effiezal Aswadi Abdul Wahab" \\ School of Accounting, \\ Curtin Business School, \\ Curtin University of Technology \\ Bentley, 1062 \\ Western Australia, Australia \\ Effiezal.abdulwahab@curtin.edu.au \\ Anwar Allah Pitchay \\ Graduate School of Business \\ Universiti Sains Malaysia \\ 11800 USM \\ Penang, Malaysia \\ Ruhani Ali \\ Graduate School of Business \\ Universiti Sains Malaysia \\ 11800 USM \\ Penang, Malaysia \\ ruhani@usm.my
}

\#Corresponding author Effiezal would like to acknowledge partial financial support for this research from the Short Term Grant, USM (304/PPAMC/6310036). 


\title{
Culture, Corporate Governance and Analysts Forecast in Malaysia
}

\begin{abstract}
This study examines the relationship between Bumiputra (in reference to Malay indigenous race) directors, a proxy for culture and analysts forecast. In addition, the study investigates whether corporate governance affects that relationship. Based on a sample from 1999 to 2009 and 664 observations, we find a positive and significant relationship between culture and analysts forecast error suggesting that Bumiputra directors lead to less transparent information environment. However, we find limited evidence to support that good governance weakens the positive relationship between Bumiputra directors and analysts forecast error.
\end{abstract}

Keywords: Ethnicity, corporate governance and analysts forecast.

Data availability: Data are publicly available from the sources identified in the paper.

JEL classifications: G34, M14 


\section{Introduction}

Financial analysts are important players in the capital market. Their role in analysing information, either publicly and privately obtained is crucial in determining the progress of firms, especially in terms of quality of earnings. There are abundance of research on role of financial analysts in the capital market with such focus on analysts' forecasts, analysts’ coverage and the effect on future income (see Bradshaw, 2011; Ramnath et al., 2008 for review of literature on analysts' research). In addition, many studies examined the determinants of analysts' forecasts. However, evidence has been limited in relation to examining the impact of cultural values of earning forecasts. Our sample country, Malaysia represents this opportunity in examining whether such association exist between cultural values and analysts forecasts.

Cultural values according to Storz (1999) assisted in shaping attitudes and business practices. Within a multicultural business setting such as Malaysia, the influence of cultural values is an important factor for the development of the Malaysian capital market. The introduction of the New Economic Policy (NEP) in 1970 was loosely based on the wealth inequality among the ethnic groups in Malaysia. The main aim of NEP is to enhance the Bumiputra shareholdings in the capital market by various means. ${ }^{1}$ Among them are by setting up institutional funds to support local companies and businesses, which are primarily run by Bumiputras. The Malaysian government policy itself was seen as positive discrimination (Gomez \&

\footnotetext{
${ }^{1}$ The term Bumiputra or 'sons of the soil' was popularized during the 1920s and 1930s by the British colony to distinguish the indigenous people of Malaya (now Malaysia), the majority of whom are Malays, from the Chinese or Indian immigrants, the non-indigenous people. Article 160 (2) of the Malaysian Constitution 1957 defines Malays as a person, who professes the religion of Islam, habitually speaks the Malay language and conforms to Malay custom.
} 
Jomo, 1999), but on one hand, the assistance is much needed to reduce wealth imbalance among ethnics.

Pryor (2007) argues that when economic institutions are not imposed by force, the cultural characteristics are more likely to determine the economic system, rather than economic institutions. This statement is partially true when we examine the studies of Mitton (2002) and Bushman et al. (2004) which suggest that Malaysia is weak in legal enforcement. We could argue that due to the relatively weak legal enforcement of rules and regulations of the capital market, cultural characteristics will take precedence in business dealings, and shapes the capital market.

Ethnicity has been closely related to cultural values. One would expect that various races or ethnic groups are subjected to their cultural values, and clearly differentiated from national culture. Malaysia is a country that represents such unique case of various cultures based on its multi-racial groups. Various studies have examined the effect of culture in Malaysia on the capital market. There are two strands of research on culture in Malaysia. The first strand of research focuses on the well-established Hofstede-Gray framework on the link between cultural values and the development of accounting values. The rationale behind the Hofstede-Gray framework is accounting choices are affected by cultural values. Gray (1988) developed accounting values based on Hofstede (1980) cultural values. ${ }^{2}$ Gray (1988) argues that cultural dimensions identified by Hofstede (1980) influence a country's accounting system in two ways; (1) through their influence on a country's institutions

\footnotetext{
${ }^{2}$ We admit that there has been some concern raised by the academic world regarding Hofstede understanding on culture. Please see Baskerville (2003) and Baskerville-Morley (2005) for some arguments against Hofstede cultural studies. Although we admit limitations exists, at the same time we believe that the cultural dimensions offered by Hofstede is the best current cultural dimension model that could be used in capital market research.
} 
such as its capital market and ; (2) through their influence on accounting values, such as conservatism, that are shared by members of the accounting subculture within a country (Doupnik, 2008). ${ }^{3}$

The outcome of the Hofstede-Gray framework suggests that Bumiputra directors are less compliant to regulations, secretive and will have lower level of disclosure as relative to Chinese directors. The seminal work of Haniffa and Cooke (2002) examine the relationship between cultural values and corporate governance disclosure in Malaysia. Contrary to their prediction based on the Hofstede-Gray framework, they find that Chinese directors are secretive and risk averse relative to the Bumiputra which reflected on the corporate governance disclosure. Other studies examine the relationship between culture with earnings quality (Abdul Rahman \& Mohammad Ali, 2006; Mohamed Yunos et al., 2012), audit related studies (Che Ahmad et al., 2006; Syed Mustapha Nazri et al., 2012), and corporate governance (Salleh et al., 2006; Yatim et al., 2006; Abdul Wahab et al., 2007). These studies rely on the Hofstede-Gray framework which argues that Bumiputras have lower level of disclosure and low level of legal compliance. The results of these studies are rather consistent throughout, and give support to the framework which link Hofstede cultural values with accounting values.

The second strand of cultural research is closely tailored to the early development of the capital market in Malaysia. Since the development of the capital market is loosely based on racial ground, studies have also treated different groups that have access to preferential treatment from the government. Gul (2006) examines the relationship between political connections and audit fees in Malaysia in which he

\footnotetext{
${ }^{3}$ Please see Doupnik and Tsakumis (2004) for a critical review of Gray (1988) accounting values.
} 
adopts Bumiputra directors as a proxy for connected firms. Johl et al. (2012) investigate the characteristics of the CEO ethnicity and audit fees. Abdul Wahab et al. (2014) adopt similar approach when examining the issue of non-audit fees and auditor independence. The premise of these papers is that the preferential treatment connected firms get, proxied by Bumiputra directors will lead to the firm being riskier and inefficient. This is further supported by financial reporting quality studies such as Bushman et al. (2004) and the possible bailout by government for connected firms (Faccio et al., 2006).

Both strand of research provide a distinctive consensus. They find companies that are dominated by Bumiputra directors will have lower level of governance, less transparent and inefficient. These factors will influence the quality of financial reporting and thus affect the information environment. Therefore, we want to investigate the relationship between cultural values and analysts forecast error, which is a good proxy for the level of information environment in the capital market. The premise of such relationship is simple; there is positive relationship between cultural values and the analysts forecast error and this implies that cultural values will lead to less accurate earnings forecast.

Financial analysts or sell-side analysts provide an excellent avenue to test the quality of financial information in the capital market. They provide a better proxy for the nature of independence in determining whether the firm is progressing well in their operations. Financial analysts depend on the amount of information made available by the firms either by means of publicly available information or purchased materials. Firms with better governance, heavily dependent on non-governmental resources or independent funding will signal better information and higher level of 
transparency, as observed by Abdul Wahab et al. (2007). Hence, analysts will have better and more information to make forecasts of future earnings.

Another important element in recent changes in Malaysia's capital market is the progress of corporate governance reforms. The primary reason for corporate governance reform in Malaysia was to boost investors' confidence, especially during the Asian Financial Crisis in 1998. Among the government's initiatives are to enhance governance structures and transparency with the introduction of Malaysian Code on Corporate Governance in 2001, the introduction of Minority Shareholders Watchdog Group lead by top local institutional investors, primarily to protect minority interests, and compulsory training for directors in relation to corporate governance. These initiatives manage to enhance transparency (Abdul Wahab et al., 2007), and increase level of earnings quality and disclosure (Haniffa \& Hudaib, 2006).

Studies have examined the effect of corporate governance in Malaysia's capital market. Haniffa and Hudaib (2006) examine the relationship between corporate governance and performance in which they find board size and top five (5) institutional shareholdings to be significantly associated with both market and accounting performance measures in Malaysia. Based on a composite index of various corporate governance measures, Abdul Wahab et al. (2007) find a positive and significant relationship with corporate governance index and market adjusted returns. Morris et al. (2011) investigate the effect of corporate governance before and after the Asian Financial Crisis. Based on two sample period of 1996 and 2001, they find corporate governance is more value relevant after the Asian Financial Crisis. These studies suggest that corporate governance does matter in Malaysia. 
The above present an interesting institutional setting in Malaysia. A 'clash' of cultural values and government efforts in enhancing level of information in the capital market, presents a case suitable for investigation. The Malaysian institutional settings provide a good avenue to test whether the mix of cultural values and rules and regulations by the government, especially in enforcing governance matters. The relationship between corporate governance and forecast accuracy is negatively expected, and thus one would expect the negative relationship between cultural values and forecast accuracy will be weaker for firms with good governance.

The issue of financial reporting quality in Malaysia is the main driver for choice of financial analysts forecast. Scarcity in earnings predictability studies in Malaysia made this research timely and further extent the current literature. Further, financial analysts have strong influence in the market place. Their recommendations could influence firm's prices, strategic decisions and market value. In addition, financial analysts have strong influence on portfolio fund managers around the world. Therefore, the accuracy of such analysts is of great importance. Studies on analysts forecast in Malaysia have been limited to examination based on multiple countries. Hope (2003) examines the relationship between disclosure practices and analysts forecast for 22 countries, Malaysia included. Yu (2010) conducts a similar study by examining the relationship between analysts' forecasts properties, analysts following and governance disclosure. Ang and Ma (2001) examine the behaviour of financial analysts in four Asian countries, namely Indonesia, Korea, Thailand and Malaysia during the financial crisis. Coen and Desfluers (2004) and Coen et al. (2005) examine the characteristics or determinants of analysts' forecasts in eight Asian emerging economies. Ahmad Zaluki and Wan Hussin (2010) examine the relationship between 
corporate governance and management earnings forecast during initial public offering. Ahmad Zaluki and Wan Hussin (2010) paper remains the sole paper that focus on (management) earnings forecast in Malaysia and this makes a sound motivation for this study.

Our study has some incremental contributions. First, we extend the work of Haniffa and Cooke (2002) as we examine the role of culture, based on the HofstedeGray framework against analysts forecast. Secondly, we add to the existing literature by investigating the interrelationship between culture, corporate governance and analysts forecast in Malaysia.

Based on a sample of 664 observations for a sample of 1999 to 2009, we find a positive and significant relationship between the percentage of Bumiputra directors and forecast error. These suggest that culture, proxied by Bumiputra directors influence the level of financial information in the capital market. We find a positive relationship between the total board directors and forecast error and this outcome suggest that bigger boards are less effective in relations to good governance. However, our extended analysis could not lend any support that corporate governance mitigates the positive relationship posited between culture and forecast error.

The structure of the paper is as follows. Institutional background discussing on Malaysia's socio and political economy and the recent development on corporate governance is presented in Section 2. Section 3 presents arguments for our empirical predictions while Section 4 discussed the research method and data description. Section 5 presents the results and Section 6 concludes. 


\section{Institutional Background}

\subsection{Malaysia socio and political economy}

Malaysian corporate ownership is divided into groups of ethnicity such as Malays, Chinese, Indian and other small minority groups. The group of ethnicity are divided into ethnic lines which can be clearly observed in the listed firm whose share ownership and board membership are dominated by two main ethnic groups namely Bumiputra Malays and the Chinese (Yatim et al., 2006). ${ }^{4}$

In Malaysia, although Indian is one of the main ethnic groups, the power in socio-economic activities and political policy making are denominated by Bumiputra Malays and Chinese (Yatim, et al., 2006). Every ethnicity has their own believes and ideology which influences the way of thinking, decision making and direction of an organisation. The term Bumiputra was coined by the British to differentiate between the indigenous (Malays) and the non-indigenous people of the then Malaya, now Malaysia. Mohammad Yusuf (2012) states three important premises on why there is a need to differentiate between Bumiputras and non-Bumiputras, although Malaysia is no longer a British colony. The first premise is the basis for division lies in the belief that Bumiputras having an indigenous status do not have a share in the economy that reflect their proportion in the population while the second premise is that the government policies should be oriented to redress this economic imbalance. The third premise is, it is believed that a more equitable participation of Bumiputras will help to

\footnotetext{
${ }^{4}$ In 2008, Malaysia's population was at 28,882 million people in which Bumiputras account for nearly 60 percent, Chinese at 22.4 percent and 6.7 percent Indian. The remaining consists of other ethnic groups.
} 
promote political stability. Historical factors and cultural characteristics appear to have significant impact on the development of the capital market. Mansor and Kennedy (2000) state that Malay cultural values have developed from a history of communal living and cooperation and are often viewed as being high on collectivism. One could argue that this historical premise lead to weak entrepreneurial skills as relative to other ethnic groups in Malaysia.

In contrast, Chinese leaders show remarkably high leadership skill and successfully lead their businesses into professionally-managed organisation. In addition, the Chinese also create protection surrounding their business by making connections with Malays prior to the introduction of the NEP in 1970 (White, 2004). Ball et al. (2003) reported that the Chinese controlled nearly 69 percent of market capitalisation, although their population stands at only 29 percent in Malaysia. Statistical figures have shown that the Bumiputra shareholdings in the capital market have been increasing steadily over the years, especially after the implementation of NEP. As at 2008, Bumiputra shareholdings stand at 21.9 percent, short of the 30 percent targeted earlier by the government. ${ }^{5}$

\subsection{Corporate Governance initiatives in Malaysia}

The topic of corporate governance is not new in Malaysia. However in the past, or specifically before the Asian Financial Crisis, the main corporate governance mechanisms relied on the rules and regulations imposed by the regulators in Malaysia.

This is in part probably due to the lack of market for corporate control (takeovers, mergers) in Malaysia (Faccio et al., 2006). As such, these regulations are

\footnotetext{
${ }^{5}$ Please see Appendix A for shareholdings distribution.
} 
largely to enforce good governance and ensure the company actually follows the rule of law. Among the acts are Companies Act (1965), the Securities Commission Act (1993), Financial Services Act (2013), Islamic Financial Services Act (2013) and also the Bursa Malaysia Listing Requirement. In addition, Malaysia became the first Asian country to set up an independent accounting standard setting body, the Malaysian Accounting Standard Board (MASB) under the provisions of Financial Reporting Act (1997). The mission of MASB is to promote quality financial reporting and thus ensuring adequacy to the needs of users of the capital markets. These bodies act as a stepping stone for further improvement of corporate governance in the market. For instance, the Securities Commission Act established in 1993 acts as a watchdog to improve the legal framework of the capital market. Further, in 1993, the Kuala Lumpur Stock Exchange Requirement required that listed firms must set up an audit committee of at least three individuals, comprising a majority of independent directors. In 1996, the Registrar of Companies introduced the Code of Ethics for directors. These initiatives are some of the efforts made prior to the Asian Financial Crisis to ensure effective corporate governance.

Further events especially during the Asian Financial Crisis in 1998 initiated a more concerted effort by the government to ensure depth in corporate governance practices. It started with the establishment of the Finance Committee on Corporate Governance (FCCG) by the Malaysian Securities Commission which then lead to the introduction of Malaysian Code on Corporate Governance in 2001 (MCCG). The MCCG is currently part of the listing requirement based on the comply-or-explain basis. Abdul Wahab et al. (2007) provide initial evidence on the effectiveness of such regulations on corporate governance disclosure and firm performance. They find after 
2001, listed firms corporate disclosure increase and this resulted in better firm performance, measured by market adjusted returns. Subsequent study by Abdul Wahab et al. (2008) finds that good governing firms attract a higher level of institutional investors. The MCCG went through several other revisions. Notably, revision in 2007, widely known as MCCG 2007, enhances the role of nomination committee and requires at least one member of audit committee to be financial literate with commitment towards an accounting association or body. The primary motivation for various corporate governance initiatives is to enhance investors' confidence in terms of rules of law governing the firms.

\section{Empirical Predictions}

\subsection{Cultural Values and Analysts Forecast Error}

We offer two arguments on the relationship between cultural values, based on the two strand of research discussed earlier. The first argument is socio-economy argument while the second one is political-economy argument. The socio-economy argument resides on the Hofstede-Gray framework that links cultural values with accounting values. Culture is define as learned, socially acquired traditions and life style of the members of a society, including their patterned, repetitious way of thinking, feeling and acting (Harris, 1987). Chuah (1995) finds Malaysian managers are influenced by race, education and type of organisation that they work for. Hofstede and Gray theoretical framework is often used to relate cultural value and accounting system (Perera, 1989; Fechner et al., 1994; Willet et al., 1995; Haniffa \& 
Cooke, 2002). Hofstede-Gray theoretical framework explained the characteristic of Bumiputra (Malay) and Chinese culture values and accounting disclosure information. Table 1 presents the framework that relates Hofstede cultural dimensions with Gray's accounting values. The four cultural dimensions are power (1) power distance; (2) masculinity; (3) uncertainty avoidance, and (4) individualism. ${ }^{6}$ Gray (1988) then developed accounting values based on these cultural dimensions. The accounting values are (1) professionalism versus statutory control; (2) uniformity versus flexibility; (3) conservatism versus optimism and (4) secrecy versus transparency. ${ }^{7}$

\section{[Table 1 about here]}

The framework shows that Bumiputra directors experience high level of power distance and uncertainty avoidance while low level of masculinity and individualism. These cultural traits of Bumiputra directors resulted in low level of professionalism

\footnotetext{
${ }^{6}$ Hofstede (1980) cultural dimensions:

i. Power distance: the extent to which the less powerful members of institutions and organisations within a country expect and accept that power is distributed unequally.

ii. Masculinity: refers to a society in which gender roles are distinct with me expected to be tough and assertive.

iii. Uncertainty avoidance: the extent to which members of a culture feel threatened by uncertain or unknown situations.

iv. Individualism: refers to a society wherein ties between members are relatively loose.

${ }^{7}$ Gray (1988) accounting values:

i. Professionalism versus statutory control: A preference for the exercise of individual professional judgment and the maintenance of professional self-regulation as opposed to compliance with legal requirements and statutory control.

ii. Uniformity versus flexibility: A preference for the enforcement of uniform accounting practices between companies and for the consistent use for such practices over time as opposed to flexibility in accordance with the perceived circumstances of individual companies.

iii. Conservatism versus optimism: A preference for a cautious approach to measurement so as to cope with the uncertainty of future events as opposed to more optimistic.

iv. Secrecy versus transparency: A preference for confidentiality and the restriction of disclosure of information about the business only to those who are closely involved with its management and financing as opposed to a more transparent, open and publicly accountable approach.
} 
and high level of secrecy, uniformity and conservatism. Based on the outcome of the Hofstede-Gray framework, these will result in low compliance with legal requirements, low disclosure and less flexibility and optimism. Overall, we could conclude that the cultural traits coupled with accounting values, will result in the firms with higher level of Bumiputra directors to experience higher risk, as supported by Gul (2006), low level of disclosure in relations to financial reporting and less compliance (Johnson \& Mitton, 2003) to capital markets regulations. Low disclosure reduces the quality of accounting information which leads to low accuracy analyst forecast. Study by Haniffa and Cooke (2002) however find contradicting result to Hofstede-Gray theoretical framework. They find Bumiputra directors have more information disclosure which contradict with the Hofstede-Gray theory. Increase of accounting information quality enhances analysts forecast. Theoretical arguments raised by studies (Haniffa \& Cooke, 2002, 2005) on socio-economy argument suggest that firms dominated by Bumiputras directors are rather weak in disclosure less compliance to rules and regulations.

The political-economy argument is based on the notion of capital market development in Malaysia that initiated by the support to the Bumiputras. Malaysia capital market is largely developed based on relationship-based economy (Gul, 2006). The political economy argument raised by the likes of Gomez and Jomo (1999), Johnson and Mitton (2002), and Gul (2006) state that these firms are dependent on government funding and has less reliance on foreign funding, are inefficient, riskier due to uncertainty in their cash inflow and are less transparent. The outcomes of these two strands of arguments are rather similar. The outcome of these arguments suggest that the information environment is not as transparent as relative to firms not 
dominated by Bumiputra directors and as such creates uncertainty in the accounting numbers made available to the public, or in this case, financial analysts. Since financial analysts, especially sell-side analysts depend on the readily available information or even purchased information from the firm, this will have an effect on the level of accuracy of their estimates.

\section{$H_{1}$ : There is a positive relationship between Bumiputra cultural values and analysts' forecast error.}

Haniffa and Cooke (2002) provide the initial evidence on cultural values and corporate governance disclosure. Previous study by Haniffa and Cooke (2002) used Hofstede-Gray framework to analyse the effect of culture on the shareholders information disclosure. Based on Hofstede-Gray theoretical framework, the Bumiputras may be expected to be secretive and result in low disclosure. Based on the Hofstede-Gray framework, they predicted that Bumiputra directors are negatively related to corporate governance disclosure. However, they find a positive and significant relationship between the ratio of Bumiputra directors and voluntary disclosure. ${ }^{8}$ Since their findings contradict their prediction, they argue there could be other factors, such as religious values that could affect the disclosure quality by Bumiputra directors. Numerous studies have since, based on the findings of Haniffa and Cooke (2002) embarked on investigating further the role of ethnicity or culture in Malaysia's capital market.

\footnotetext{
${ }^{8}$ This result is based on a reduced regression analysis. The primary regression yield insignificant results.
} 


\subsection{Corporate Governance and Analysts Forecast Error}

The central argument for this empirical prediction between corporate governance and analysts forecast revolves around information asymmetry caused by the agency conflict between managers and shareholders, or principal. The role of the corporate governance is to mitigate the information asymmetry and thus will make the information more transparent and available for shareholders or other stakeholders. In addition, good governance mitigates uncertainty in future earnings due to it expected monitoring role by various governance mechanisms. Bhat et al. (2006) state two reasons why corporate governance is important to financial analysts. The first reason related to the integrity of the financial disclosures since insiders are the major source of financial disclosure. The second reason relates to the role of corporate governance in reducing uncertainty surrounding future performance.

The corporate governance mechanism in this paper comprises of duality, board independence, board size and ownership structures. Prior studies find the presence of CEO duality in an organisation reflects poor governance (Jensen, 1993; Yermack, 1996). Byrad et al. (2006) finds the presence of CEO duality in organisation has negative relationship with the accuracy of analysts' forecast. Core et al. (1999) specify that fewer independent of Board of director cause for poor monitoring. Karamanou and Vafeas (2005) find that adding more independent board will increase the company monitoring diligence. Thus, board independence has positive relationship with the accuracy of analysts' forecast (Byrad et al., 2006). Board director size refers to the total number of directors in the organisation. WanHussin et al. (2010) finds that board size has negative relationship with (management) 
analysts' forecast. The participation of institutional ownership such as pension funds, trust funds and others, enhance monitoring and ensure that firm performance is enable to provide return on investment. Ackert and Athanassakos (1997) find institutional ownership has positive relationship to company performance and analysts forecast. Therefore we state, the following hypothesis in the alternative form:

$\mathrm{H}_{2}$ : There is a negative relationship between corporate governance variables and analysts' forecast error

\subsection{Culture, Corporate Governance and Analysts Forecast Error}

This empirical prediction investigates effect on corporate governance on the relationship between culture and analyst forecast error. We predicted earlier that a positive relationship exist between culture and analysts' forecast error, which means that the higher proportion of Bumiputra directors lead to larger forecast error. In contrast, we predicted a negative relationship between corporate governance variables and forecast error. Since corporate governance is expected to enhance monitoring, one would expect that the positive relationship between culture and forecast error would be weaker for firms with good governance. Therefore we state the following hypothesis, in alternative form:

$H_{3}$ : The positive relationship between cultural values and analysts

forecast error would be weaker for firms with good governance 


\section{Data and Research Methods}

This study is based on sample of 664 firm-year observations presenting 193 firms listed on Bursa Malaysia for period of 1999 to 2009. The sample firms from the Institutional Broker Estimate System (I/B/E/S) database are used and matched them with Compustat Global for firm specific information. Next, the corporate governance variables and Bumiputra directors from annual reports for firm were identified. We posit the following regression model to test our hypotheses:

$$
\begin{aligned}
& F E_{i t}=\alpha_{0}+\beta_{1} B U M I+B_{2} \text { DUALITY }_{i t}+\beta_{3} \text { BODIND }_{i t}+\beta_{4} \text { LNBODSIZE }_{i t}+\beta_{5} \\
& \text { INSTOWN }_{i t}{ }^{+} \quad \beta_{6} \text { MANOWN }_{i t}{ }^{+} \quad \beta_{7} \text { LNNUMEST }_{i t}{ }^{+} \quad \beta_{8} \text { LNHORIZON }_{i t}{ }^{+} \\
& \beta_{9} \text { MKTCAP }_{i t}+\beta_{10} \text { BIGN }_{i t}+\beta_{11} \text { XLIST }_{i t}+\beta_{12} \text { STROA }_{i t}+ \\
& \beta_{13} \text { INDUSTRIES }_{i t}+\beta_{14} \text { PERIOD }_{i t}+\varepsilon i t
\end{aligned}
$$

\subsection{Measure for Analysts Forecast Error}

The dependent variable in the above equation is accuracy of analysts' forecast. Chang et al. (2007) use forecast error to measure firm performance; Kohlbeck and Mayhew (2010) use analysts forecast to examine quality of accounting information. Byard et al. (2010) use forecast error to measure transparency of financial reporting. Unlike other studies mentioned above, this study used forecast error to measure effect of corporate governance and culture to accuracy of analysts' forecast. Accuracy of analysts forecast is measured by forecast error $(F E)$. In formula form, forecast error $(F E)$ is written as: 
FORECAST ERROR $(F E)=\operatorname{LN}\left(\operatorname{ABS}\left(\frac{(\text { Actual Forecast-Median Forecast })}{(\text { Price })}\right)\right)$

Where ACTUAL FORECAST is the actual annual earnings as reported by I/B/E/S; MEDIAN FORECAST is the median of analysts' forecast for a year period; and PRICE is the stock price last day prior the announcement date of earning per share.

\subsection{Culture (BUMI)}

Similar to numerous Malaysian studies (e.g. Haniffa \& Cooke, 2002; Syed Mustapha Nazri et al., 2012), we opted for the percentage of Bumiputra directors as our choice of culture variable. In addition, since our arguments are based from the well-established Hofstede-Gray framework, it is only logical to choose an ethnic group as our proxy for culture. Bumiputra directors (BUMI) is measured as the percentage of Bumiputra directors on the board.

\subsection{Corporate Governance ${ }^{9}$}

This study will look into four (4) dimensions of corporate governance factors; duality (DUALITY), board independence (BODIND), and board size (BODSIZE) as

\footnotetext{
${ }^{9}$ When studying the association between corporate governance and analysts forecast, we treat governance structures as exogenous. Our approach is the same as that of Core et al. (1999) where they observe that "Following most prior empirical research in this area, we treat the board and ownership structures as exogenous, when economic theory would argue that these variables are endogenous." This well-established approach of treating governance structures as exogenous is reasonable, in the sense that some institutional features of contracting cause governance characteristics to be "sticky." For example, directors serve for fixed terms, so naturally it takes time to change board members to adjust to a changed operating environment. Consistent with many prior studies, we argue that it is difficult for firms to have optimal governance structures at all times (e.g., see Larcker et al., 2007).
} 
internal governance while external governance is tested by institutional ownership (INSTOWN).

\subsubsection{Duality (DUALITY)}

Duality (DUALITY) refers to separation of chief executive officer (CEO) from the chairman of the board. This variable is measured as a dummy variable equal to one when CEO and chairman is separated or zero otherwise. MCCG (2001) recommends a separation between the position of CEO and chairman to ensure a balance of power and authority. Proponents of combining these positions suggest that such method helps the person-in-charge and will have minimal interference in relation to decision making. In addition, combining such position will enhance and hasten decision making process and ensure that objectives of the firms are being met in a timely manner (Dahya et al., 1996). Opponents of having these two positions given to an individual suggest that the CEO needs monitoring and such practice could lead to opportunistic behaviour (Jensen \& Meckling, 1976). Jensen (1993) and Yermack (1996) argue that the combination of these two positions to a sole individual is an indicator of poor governance. We predict a negative relationship between DUALITY and FE suggesting that firms that separate the CEO and Chairman functions will have better monitoring function and thus provide better governance mechanism for the firm. Therefore, it create better information environment and creates transparency. Byard et al. (2006) find a negative relationship between firms that combine such function with analyst forecast accuracy. 


\subsubsection{Board Independence (BODIND)}

Our second corporate governance variable is board independence which is the proportion of independent directors on the board of directors. The premise of this variable resides on the notion of agency issues between the managers or directors and shareholders whom are the owners of the firms. The presence of independent directors mitigate any agency problem by exercising proper monitoring on executive directors. Core et al. (1999) indicate that less independent outside directors provide poor monitoring and thus we expect a negative relationship between the percentage of independent directors and analysts forecast error. Klein (2002) finds that independent directors on board improve the integrity of the financial accounting process through their more effective monitoring. Further, Fama and Jensen (1983) argue that effectiveness of board monitoring depends on the independence of board members. Adut et al. (2011) find that the percentage of independent directors is related to likelihood of meeting and exceeding consensus forecast. Byard et al. (2006) find a positive and significant relationship between the percentage of independent directors and forecast accuracy.

\subsubsection{Board Size (LNBODSIZE)}

Our third internal corporate governance mechanism is the size of board of directors. The effect of board size is rather ambiguous. Small boards are viewed to be more effective as they could make sound decision in a shorter period of time as relative to a bigger board (Jensen, 1993). As such, as the number of board of directors 
grows, policies are being argued thoroughly and could make the decisions being conveyed at a slower pace and make them less effective (Yermack, 1996). Furthermore, as the number of directors grows, the role of board of directors is rather symbolic rather than serving a monitoring purpose (Hermalin \& Weisbach, 2000). Hence, one could view that the monitoring by board of directors weaken as their number grows.

Alternatively, the number of directors could demonstrate economies of scale. It could provide resources to the firms through the connections obtain from directors. Haniffa and Hudaib (2005) argue that a small board may be seen to be more effective to improve performance and to limit directors' incentives to shirk, as the role performance of each member is easier to monitor and decisions can be made more quickly. On the other hand, bigger boards could provide the diversity needed to secure critical resources and contacts. Byard et al. (2006) find a negative relationship between the total number of directors on board and forecast accuracy suggesting that the larger the board, the less effective it will be in relationship of monitoring and good governance. Based on these competing arguments, we predict a relationship between the number of directors on the board and forecast accuracy. Our operational definition for board size is the natural log transformation of the number of directors on board (LNBODSIZE).

\subsubsection{Institutional Ownership (INSTOWN)}

Our external corporate governance mechanism is the percentage of top five (5) institutional ownership. Institutional investors are expected to play a fiduciary role 
and acts in the best interest of their contributors (Hawley \& Williams, 1997). In addition, Jennings (2005) argues that the size of the institutional investors could act as an important tool to exert influence over their investments. The expectations of such role for institutional investors in Malaysia are no different. In addition, the establishment of Minority Shareholders Watchdog Group in 2001 in Malaysia act as a catalyst for institutional investors in Malaysia to play a more active role in corporate governance in Malaysia.

Evidence of the governance role of institutional investors in Malaysia is rather consistent. Abdul Wahab et al. (2007) find a positive relationship between institutional ownership and firm performance. In addition, Abdul Wahab et al. (2008) find a positive and significant relationship between institutional ownership and corporate governance. Ammer and Abdul Rahman (2011) find firms targeted by institutional investors experience abnormal returns surrounding the announcement by them. Therefore, we predict a negative relationship between institutional ownership (INSTOWN) and FE. 


\subsection{Other Determinants of Analysts Forecast}

Direct managerial ownership MANOWN is the proportion of shares held by CEO and executive directors. Baik et al. (2007) find analysts' forecasts declines as managerial ownership increases. Analysts following (LNNUMEST) are the natural log transformation of the numbers of analysts following a firm. Eng and Mark (2003) find analyst following is negatively correlated to forecast error. Thus, we predict negative relationship between analysts following and analysts forecast error. Forecast horizon (LNHORIZON) is the natural log transformation of the day's basis which calculates the difference between the actual date and forecast date. Previous study finds shorten forecast horizon tend to result in less error and are less extreme (Capstaff et al., 1995). This means the longer the forecast horizon, the more exposure to error and more extreme. Thus, we predict positive relationship between forecast horizon and analysts forecast error. Firm size refers to firm's market capitalisation (MKTCAP). Company assets show the capability and strength of the market to compete in the market. Jelic et al. (1998) argues positive relationship between the larger firm sizes to forecast accuracy. Thus, we predict negative relationship between firm size and analysts forecast error. Auditor size (BIGN) comprised of Deloitte Touche Tohmatsu, Ernst \& Young, KPMG and PriceWaterhouse Coopers. This variable is measured as a dummy variable equal to one when firm appoint Big 4 or zero otherwise. Behn et al. (2008) suggest that financial reporting reliability increases with audit quality, which they infer from auditor size and industry specialisation. Behn et al. (2008) state that brand name auditors are viewed as providing higher quality audits based on their perceived competence and independence. Therefore, it is likely that a financial analysts forecast 
ability increases with the quality or reliability of financial information they use to predict future earnings (Behn et al., 2008). Therefore, we predict negative relationship between $B I G N$ and analysts forecast error.

XLIST takes the value of 1 if the firm is cross listed overseas. Risk refers to firms' standard deviation on return on asset (STROA). This variable determines the firm level of uncertainty in market condition. The risk is measured on the return on asset over three years. Huang et al. (2006) find firm with low risk has better corporate governance and better accuracy of analysts forecast. We predict positive relationship between standard deviation of return on asset and analyst forecast.

We have included industries dummies (INDUSTRIES) to control for the variation on analysts forecast among industries in Malaysia. ${ }^{10}$ Further, to control for any unobserved effect during the sample period, we have included year dummies (PERIOD) for the years 2007 and 2008.

[Table 2 about here]

\subsection{Sample Description}

Table 3 presents the firm-year observations based on the industries. Consumer product based (CONSUMER) presents the highest 198 (29.82 percent) observations while the lowest firm-year observations is the health industry (HEALTH) at 15 (2.26 percent). Construction based industry (CONSTRUCT) have the second highest number of firm-year observations at 125 (18.83 percent).

\footnotetext{
${ }^{10}$ The industries classification for this study are: agriculture, construction, manufacturing, consumer, transportation, wholesale, health, hotel and others.
} 
[Table 3 about here]

Table 4 presents the descriptive statistics. The average $F E$ is -4.334 with a range between -10.113 to 3.260 . Panel $\mathrm{B}$ tabulates the descriptive figures for the independent variables. The average number of Bumiputra directors (BODBUMI) stands at 3.15 with a maximum participation of 12 directors. On average there are 43\% of Bumiputra directors (BUMI) on board. Further, 68.6 percent of sample firms separate (DUALITY) the CEO and Chairperson functions. While 36 percent of the directors on board are independent (BODIND) with a maximum percentage of nearly 86 percent. This percentage supports the current rules and regulations by both the MCCG and Bursa Malaysia Listing Requirements that at least a third of the directors must be independent. The average size for board of directors (BODSIZE) is 7.23 directors with a range of between three (3) to 17 directors. The mean percentage for institutional shareholdings (INSTOWN) is 17.04 percent with a maximum of 94 percent of total shareholdings of firms.

Panel C of Table 4 tabulates the descriptive results for the control variables. Direct managerial shareholdings $(M A N O W N)$ averages at 5.218 percent with a maximum of 70.755 percent. The average number of analysts (NUMEST) following a firm is 6.447 with a range of between 1 to 31 analysts. The forecast horizon (HORIZON) averages 56.74 days with a maximum number of days difference of 330 between the forecast and actual announcement of the earnings figure. 76.1 percent of the sample firms are audited by Big 4 auditors and only 6.2 percent of sample firms 
are cross listed (XLIST) abroad. The average STROA is 4.997 with a maximum of 41.971.

[Table 4 about here]

\section{Results}

\subsection{Univariate Analysis}

Table 5 tabulates the correlations analysis for the variables used in this study. Both Pearson $(0.111, p<0.01)$ and Spearman-rank $(0.112, p<0.01)$ correlations between $F E$ and $B U M I$ record a positive and significant relationship, providing initial evidence that the higher proportion of Bumiputra directors result in larger forecast error. We observed negative and significant correlations (both Pearson and Spearmanrank) between FE and LNNUMEST and MKTCAP*. Further, a positive and significant correlations for Pearson $(0.170, p>0.01)$ and Spearman-rank $(0.146, p<0.01)$ giving initial support that the larger the forecast horizon the larger the forecast error. Overall results suggest no severe multicollinearity problem exist in the regressions.

[Table 5 about here]

We extend the univariate analysis by examining the differences in mean and median between firms that are below and above the median value for the number of Bumiputra directors, presented in Table 6. We find significant differences for both mean and median between these two samples for $F E$ as the firms with more than three (3) Bumiputra directors record significantly higher forecast error. We observed 
significant differences between these two samples for the corporate governance variables, with the exception of BODIND. Both of our univariate analysis provide support that a positive relationship exist between the proportion of Bumiputra directors and forecast error.

\section{[Table 6 about here]}

\section{$5.2 \quad$ Multivariate Analysis}

Table 7 tabulates the regression analysis. ${ }^{11}$ Column 1 of Table 7 presents the results without the interaction terms between $B U M I$ and the corporate governance variables. Column 1 of Table 7 documents a positive and significant relationship between $B U M I$ and FE $(0.008, t=2.979, p<0.01)$. This supports our hypothesis that Bumiputra directors are more secretive and low on disclosure, which is based on the Hofstede-Gray framework. This finding also support our second argument that firms with Bumiputra directors showed characteristics of political connections in which these firms are inefficient (Johnson \& Mitton, 2003) and weak on corporate governance. The positive relationship also suggests that these firms have less amount of information for financial analysts to assess and make sound judgment from. We find a significantly positive relationship between LNBODSIZE and FE (0.895, $t=2.840, p<0.01$ ), inferring that the larger the board of directors, the larger the forecast error. Our results support the argument raised by Yermack (1996) that bigger

\footnotetext{
${ }^{11}$ For the sake of brevity, the regressions are presented without the coefficients for industries and period dummies. The industries variables (based on Table 3), yield insignificant results. Therefore, we could conclude that the variation of analysts forecast error are not affected by industry classifications. In addition, the period $\mathrm{F}$ test for the period is $2.169, p<0.05$. Therefore, the period effects during the sample period are significant. Regression results with industries and period dummies can be obtain from the corresponding author.
} 
boards are less effective in terms of monitoring. We could not find any support for the remaining corporate governance variables effects on the forecast error. Our main control variables which are analysts following (LNNUMEST), forecast horizon (LNHORIZON) and firm size (MKTCAP) are significant and remain robust throughout the regressions models.

We extended the initial regression model by introducing interaction terms from column 2 to column 6, in which column 6 presents the final regression that includes all the interaction terms between corporate governance variables and BUMI. The only interaction term that is significant is BUMI and BODIND which is positively associated with FE. Based on column 3 and 6, the coefficient of BUMI*BODIND suggest that the presence of Bumiputra directors weakens the negative, but insignificant relationship between BODIND and FE.

[Table 7 about here]

\section{Conclusion}

We investigate the relationship between cultural values, proxy by the proportion of Bumiputra directors on board and analysts forecast error. Further, we investigate the relationship between corporate governance and forecast error. We find a positive relationship between the proportion of Bumiputra directors and forecast error. Our findings support the Hofstede-Gray framework which suggests that Bumiputras are individualistic and secretive that leads to less disclosure quality. As for our corporate governance mechanisms, we find a positive relationship between size of the board of directors and forecast error. We then extended our analysis by 
examining the interaction term between culture and corporate governance against forecast error. We find that the presence of corporate governance mechanisms do not improve or weakens the positive relationship between culture and forecast error.

Our study is not without any caveats. Our study depends on data availability from the $\mathrm{I} / \mathrm{B} / \mathrm{E} / \mathrm{S}$ database and that could represent some degree of biasness towards our findings. Furthermore, due to lack of data availability, we did not control for other variables that are proven to be significant in Malaysia's capital market such as the role of audit committee. However, we view our study as catalysts for further research on financial analysts in the future. 


\section{References}

Abdul Rashid, M. Z., and Ho, J. A. (2003). "Perceptions of Business Ethics in a Multicultural Community: The Case of Malaysia”. Journal of Business Ethics, Vol. 43 No. (1 and 2), 75-87.

Abdul Rahman, R., and Mohamed Ali, F. H. (2006). "Board, Audit Committee, Culture and Earnings Management: Malaysian Evidence”. Managerial Auditing Journal, Vol. 21 No. 7, 783-804.

Abdul Wahab, E. A., How, J., and Verhoeven, P. (2007). "The Impact of the Malaysian Code on Corporate Governance: Compliance, Institutional Investors and Stock Performance”. Journal of Contemporary Accounting and Economics, Vol. 3 No.2, 106-129.

Abdul Wahab, E.A., How, J. \& Verhoeven, P., (2008). Corporate Governance and Institutional Investors: Evidence from Malaysia. Asian Academy of Management Journal of Accounting and Finance, Vol. 4 No. 2, pp.67-90.

Abdul Wahab, E. A., Mat Zain, M., and Abdul Rahman, R. (2014). "Political Connections: A Threat to Auditor Independence?” Journal of Accounting in Emerging Economies, Forthcomin.

Ackert, and Athanassakos. (1997). "Prior Uncertainty, Analysts Bias And Subsequent Abnormal Returns”. Journal Of Financial Research, Vol. 78, 263-273.

Ackert, L. F., and Athanassakos, G. (2003). "A Simultaneous Equation Analysis of Analysts' Forecast Bias, Analyst Following and Institutional Ownership”. Journal of Business Finance and Accounting, Vol. 30 No.7, pp. 1017-1041.

Adut, D., Duru, A., \& Galpin, W. L. (2011). The Role of Corporate Governance in Meeting or Beating Analysts' Forecast. Journal of Accounting and Public Policy, Vol. 30 No. 2, pp. 188-198.

Ahmad Zaluki, N. and Wan Hussin, W.N., 2010. Corporate Governance and Earnings Forecast Accuracy. Asian Review of Accounting, Vol. 18 No.1, pp.50-67.

Ammer, R., and Abdul Rahman, R. (2009). "The Impact of Minority Shareholder Watchdog Group Activism on the Performance of Targeted Firms in Malaysia”. Asian Academy of Management Journal of Accounting and Finance, Vol. 5 No.1, pp. 67-92.

Ang, J. S., and Ma, Y. (2001). "The Behavior of Financial Analysts during the Asian Financial Crisis in Indonesia, Korea, Malaysia, and Thailand”. Pacific-Basin Finance Journal, Vol. 9 No. 3, pp. 233-263 
Baik, B., Kang, J. and Morton, R. (2007). "Managerial Ownership And Information Opacity”. Working Paper, Michigan State University,371-406

Baskerville, R. F. (2003). "Hofstede Never Studied Culture”. Accounting, Organizations and Society, Vol. 28 No. 1, pp. 1-14.

Baskerville-Morley, R. F. (2005). "A Research Note: The Unfinished Business of Culture”. Accounting, Organizations and Society, Vol. 30 No. 4, pp. 389-391.

Behn, B., Choi, J., and Kang, T. (2008). “Audit Quality and Properties of Analyst Earnings Forecasts”. The Accounting Review, Vol. 83 No. 2, pp. 327-349.

Bhat, G., Hope, O.-K. \& Kang, T., 2006. Does Corporate Governance Transparency Affect The Accuracy Of Analyst Forecasts? Accounting \& Finance, Vol. 46 No. 5, pp.715-732.

Bradshaw, M. T. (2011). “Analysts' Forecasts: What Do We Know after Decades of Work?” SSRN eLibrary. Retrieved from http://ssrn.com/paper=1880339

Braun, G.P. \& Rodriguez Jr, R.P., 2008. Earnings Management and Accounting Values: A test of Gray (1988). Journal of International Accounting Research, Vol. 7 No. 2, pp.1-23.

Brown, L. (2001). “A Temporal Analysis Of Earnings Surprises: Profits Versus Losses”. Journal Of Accounting Research, Vol. 41, 221-242.

Bushman, R., Piotroski, J., and Smith, A. (2004). "What Determines Corporate Transparency?” Journal of Accounting Research, Vol. 42 No. 2, pp. 207-252.

Byard, D., Li, Y. \& Weintrop, J., 2006. Corporate governance and the quality of financial analysts' information. Journal of Accounting and Public Policy, Vol. 25 No. 5, pp.609-625.

Callen, J. L., Morel, M., and Richardson, G. (2010). "Do Culture And Religion Mitigate Earnings Management? Evidence from a Cross-Country Analysis.” International Journal of Disclosure and Governance, Vol. 8 No. 2, pp. 103-121.

Callen, J.L., (2011). "Do Culture and Religion Mitigate Earnings Management? Evidence from a Cross-country Analysis” . International Journal of Disclosure and Governance Vol. 8, pp. 103-121.

Capstaff, J., Paudyal, K., and Rees, W. (1995). "The Accuracy And Rationality Of Earnings Forecast UK Analysts". Journal Of Business Finance And Accounting , 6987.

Chang, J., Cho, Y. J., \& Shin, H. (2007). The Change in Corporate Transparency of Korean Firms after the Asian Financial Crisis: An Analysis Using Analysts' Forecast 
Data. Corporate Governance: An International Review, Vol. 15 No. 6, pp. 11441167.

Che Ahmad, A., Shafie, R., and Mohamad Yusof, N. Z. (2006). "The Provision of Non-audit Services, Audit Fees and Auditor Independence.” Asian Academy of Management Journal of Accounting and Finance, Vol. 2 No. 1, pp. 21-40.

Chuah, B. (1995, March). “The Unique Breed Of Malaysian Managers.” Management Times, New Straits Times Press Malaysia.

Coën, A., and Desfleurs, A. (2004). “The Evolution of Financial Analysts' Forecasts on Asian Emerging Markets”. Journal of Multinational Financial Management, Vol. 14 No. 4-5, pp. 335-352.

Coën, A., Desfleurs, A., L’Her, J.-F., and Suret, J.-M. (2005). “Another Look at Factors Explaining Quality of Financial Analysts' Forecasts: Evidence From The Asian Emerging Markets.” Journal of Multinational Financial Management, Vol. 15 No. 4-5, pp. 414-434.

Core, J. E., Holthausen, R. W., and Larcker, D. F. (1999). “Corporate Governance, Chief Executive Office Compensation, and Firm Performance.” Journal of Financial Economics, Vol. 51, pp. 371-406.

Cormier and Martinez . (2006). "The Association Between Management Earning Forecast, Earning Management And Stock Market Valuation: Evidence From French IPO.” International Journal Of Accounting , Vol. 41, pp. 209-236

Desender, K. A., Castro, E. C., and Leon, S. A. (2011 ). "Earnings Management and Cultural Values”. American Journal of Economics and Sociology, Vol. 70, No. 3 , pp. 640-670.

Doupnik, T. S. (2004). “A Critical Review of Tests of Gray's Theory of Cultural Relevance and Suggestions For Future Research”. Journal of Accounting Literature Vol.23, 1-48.

Doupnik, T. S., and Tsakumis, G. T. (2004). “A Critical Review of Tests of Gray's Theory of Cultural Relevance and Suggestions for Future Research". Journal of Accounting Literature, Vol. 23, pp. 1-48.

Eng, L., and Mak, Y. (2003). "Corporate Governance And Voluntary Disclosure.” Journal of Accounting and Public Policy, Vol. 22, pp. 325-45

Faccio, M., Masulis, R., and McConnell, J. J. (2006). "Political Connections and Corporate Bailouts”. Journal of Finance, Vol. 61(6), pp. 2597-2635. 
Fechner, H. And A. Kilgore. (1994). "The Influence Of Cultural Factors On Accounting Practice." The International Journal Of Accounting Education And Research, 29 No. 3, pp. 265-277.

Gomez, E. T., and Jomo, K. S. (1999). "Malaysia’s Political Economy: Politics, Patronage and Profits”. Cambridge: Cambridge University Press.

Governance, M. C. (2001). Malayan Law Journal Sdn Bhd .

Gray, S. J. (1988). "Towards a Theory of Cultural Influence on the Development of Accounting System Internationally”. Abacus, Vol. 24 No. 1, pp. 1-15.

Guan, L., Pourjalali, H., Sengupta, P., and Teruya, J. (2005). "Effect of Cultural Environment on Earnings Manipulation: A Five Asia-Pacific Country Analysis.” The Multinational Business Review, Vol 13 No. 2, pp. 23-40.

Gul, F. A. (2006). “Auditors' Response to Political Connections and Cronyism in Malaysia.” Journal of Accounting Research, Vol. 44 No. 5, pp. 931-963.

Haniffa, R., and Cooke, T. (2002). "Cultural, Corporate Governance and Disclosure in Malaysian Corporation”. Abacus , Vol. 38 No. 3, pp. 317-349.

Haniffa, R. M., and Cooke, T. E. (2005). "The Impact of Culture and Governance on Corporate Social Reporting”. Journal of Accounting and Public Policy, Vol. 24 No. 5, pp. 391-430.

Haniffa, R., and Hudaib, M. (2006). "Corporate Governance Structure and Performance of Malaysian Listed Companies”. Journal of Business Finance and Accounting, Vol. 33 No. 7-8, pp. 1034-1062.

Harris, M. (1987). “Cultural Anthropology”. Harper And Row,58.

Hashim, H. A., and Devi, S. (2009). "Board Characteristics, Ownership Structure and Earnings Quality: Malaysian Evidence”. Research in Accounting in Emerging Economies, Vol. 8, pp. 97-123.

Hawley, J. P., and William, A. T. (1997). “The Emergence of Fiduciary Capitalism.” Corporate Governance: An International Review, Vol. 5 No. 4, pp. 206-213.

Hofstede, G. (1980). "Culture and organizations." International Studies of Management and Organization, Vol. 10 No. 4, pp. 15-41.

Hofstede, G. (1991). "Management in Multicultural Society.” Malaysian Management Review, Vol. 26 No. 1, pp. 3-12.

Hope, O.-K. (2003). “Accounting Policy Disclosures and Analysts' Forecasts.” Contemporary Accounting Research, Vol. 20 No. 2, pp. 295-321. 
Jelic,Saadouni and Briston.(1998). "The Accuracy Of Earning Forecast In IPO Prospectuses On The Kuala Lumpur Stock Exchange”. Accounting and Business , Vol. 57-62.

Jennings, W. W. (2005). "Further Evidence on Institutional Ownership and Corporate Value.” Advances in Financial Economics, Vol. 11, pp. 167-207.

Johl, S., Subramaniam, N., and Mat Zain, M. (2012). “Audit Committee and CEO Ethnicity and Audit fees: Some Malaysian evidence." The International Journal of Accounting, Vol. 47 No. 3, pp. 302-332.

Johnson, S., and Mitton, T. (2003). "Cronyism and Capital Controls: Evidence from Malaysia.” Journal of Financial Economics, Vol. 67, pp. 351-382.

Karamanou, I. \& Vafeas, N., 2005. The Association between Corporate Boards, Audit Committees, and Management Earnings Forecasts: An Empirical Analysis. Journal of Accounting Research, Vol. 43 No. 3, pp.453-486.

Kohlbeck, M., \& Warfield, T. (2010). Accounting Standard Attributes and Accounting Quality: Discussion and Analysis. Research in Accounting Regulation, Vol. 22 No. 2, 59-70.

Larcker, D. F., Richardson, S. A., and Tuna, Ä․ (2007). "Corporate Governance, Accounting Outcomes, and Organizational Performance.” Accounting Review, Vol. 82 No. 4, 963-1008.

Li, J., and Harrison, J. R. (2008). "Corporate Governance and National Culture: a multi-country study.” Corporate Governance, 607-621.

Malaysia. (1971). Second Malaysia Plan, 1971-1975.

Malaysia. (1976). Third Malaysia Plan, 1976-1980.

Malaysia. (1981). Fourth Malaysian Plan, 1981-1985.

Malaysia. (1990). Sixth Malaysian Plan, 1990-1995.

Malaysia. (2001). Third Outline Perspective Plan, 2001-2010

Malaysia. (2006). Ninth Malaysian Plan

Malaysia. (2011). Tenth Malaysia Plan, 2011-2015.

Malaysian Code Of Corporate Governance. (2001). Malayan Law Journal Sdn Bhd . 
Mansor, N., and Kennedy, J. (2000). "Malaysian Culture and the Leadership of Organizations: A Globe Study”. Malaysian Management Review, Vol. 35 No. 2, pp. 44-53.

Mohamad, M. H. S., Rashid, H. M. A., and Shawtari, F. A. M. (2012). "Corporate Governance and Earnings Management in Malaysian Government Linked Companies: The impact of GLCs' transformation policy.” Asian Review of Accounting, Vol. 20 No. 3, pp. 241-258.

Mohamed Yunos, R., Ismail, Z. \& Smith, M., 2012. Ethnicity and Accounting Conservatism: Malaysian Evidence. Asian Review of Accounting, 20 No. 1, pp.34-57.

Mohamad Yusuf, N.Z., 2012. Bumiputera Institution and the Development of Corporate Governance in Malaysia. The University of Manchester, Manchester, UK.

Morris, R. D., Pham, T., \& Gray, S. J. (2011). The Value Relevance of Transparency and Corporate Governance in Malaysia before and After the Asian Financial Crisis. Abacus, Vol. 47 No. 2, pp. 205-233.

Mitton, T. (2002). "A Cross-Firm Analysis of the Impact of Corporate Governance on the East Asian Financial Crisis.” Journal of Financial Economics, Vol. 64 No. 2, pp. 215-241.

Nelson, S. P., and Devi, S. (2013). “Audit Committee Experts and Earnings Quality.” Corporate Governance, Vol. 13 No. 4, pp. 1-11.

Perera, H. (1989). "Towards a Framework to Analyse the Impact of Culture on Accounting.” International Journal of Accounting, Vol. 24, pp. 42-56.

Pryor, F. L. (2007). “Culture and Economic Systems.” American Journal of Economics and Sociology, Vol. 66, No. 4 , pp. 818-855.

Ramnath, S., Rock, S., and Shane, P. (2008). "The Financial Analyst Forecasting Literature: A Taxonomy With Suggestions For Further Research.” International Journal of Forecasting, pp. 34-75.

Salleh, Z., Stewart, J., and Manson, S. (2006). "The Impact of Board Composition and Ethnicity on Audit Quality: Evidence from Malaysian Companies.” Malaysian Accounting Review, Vol. 5 No. 2, pp. 61-83.

Smale, J., Patricoft, A., Marcus, B., and Johnson. (1995). "Redraw The Line Between Board And The CEO” Harvard Business Review , 5-12.

Storz, M. L. (1999). Malay and Chinese Values Underlying The Malaysian Business Culture. International Journal of Intercultural Relations, Vol. 23 No. 1, pp. 117-131. 
Syed Mustapha Nazri, S. N. F., Smith, M., and Ismail, Z. (2012). "The Impact of Ethnicity on Auditor Choice: Malaysian Evidence.” Asian Review of Accounting, Vol. 20 No. 3, pp. 198-221

Wan Ismail, W. A., Kamarudin, K. A., Van Zijl, T., and Dunstan, K. (2013). "Earnings Quality and the Adoption of IFRS-Based Accounting Standards: Evidence from an Emerging Market.” Asian Review of Accounting, Vol. 21 No. 1, pp. 53-73.

Willett, R., Baydoun, N. And A. Nishimura, A. (1997). "Environmental Considerations in Studying Accounting in” The Asian Pacific Region, 35.

Yatim, P., Kent, P. \& Clarkson, P., 2006. Governance Structures, Ethnicity, and Audit Fees of Malaysian Listed Firms. Managerial Auditing Journal, Vol. 21 No. 7, pp.757-782.

Yermack, D., 1996. Higher Market Valuation of Companies with a Small Board of Directors. Journal of Financial Economics, 40 No. 2, pp.185-211.

Yu, M. (2010). “Analyst Following and Corporate Governance: Emerging Market Evidence.” Accounting Research Journal, Vol. 23 No. 1, 69-93. 
Appendix A: Ownership of Share Capital in Limited Firms (1969-2008)

\begin{tabular}{lcccccccccc}
\hline & 1969 & 1970 & 1975 & 1980 & 1985 & 1990 & 1995 & 2000 & 2004 & 2008 \\
\hline Total Bumiputras & 1.5 & 2.4 & 9.2 & 12.4 & 18.5 & 19.3 & 20.6 & 18.9 & 18.9 & 21.9 \\
Individual & 1.0 & 1.6 & 3.6 & 4.3 & $\mathrm{n} / \mathrm{a}$ & 14.2 & 18.6 & 14.2 & 15.0 & $\mathrm{n} / \mathrm{a}$ \\
Institutions & 0.5 & $\mathrm{n} / \mathrm{a}$ & $\mathrm{n} / \mathrm{a}$ & $\mathrm{n} / \mathrm{a}$ & $\mathrm{n} / \mathrm{a}$ & $\mathrm{n} / \mathrm{a}$ & $\mathrm{n} / \mathrm{a}$ & 3.0 & 2.2 & $\mathrm{n} / \mathrm{a}$ \\
Trust Agencies & $\mathrm{n} / \mathrm{a}$ & 0.8 & 5.6 & 8.1 & $\mathrm{n} / \mathrm{a}$ & 5.1 & 2.0 & 1.7 & 1.7 & $\mathrm{n} / \mathrm{a}$ \\
\hline $\begin{array}{l}\text { Total Non- } \\
\text { Bumiputras }\end{array}$ & 34.3 & 34.3 & 37.5 & 40.1 & 49.5 & 46.8 & 43.4 & 41.3 & 40.6 & 36.7 \\
Chinese & 22.8 & 27.2 & $\mathrm{n} / \mathrm{a}$ & $\mathrm{n} / \mathrm{a}$ & 48.2 & 45.5 & 40.9 & 38.9 & 39.0 & $\mathrm{n} / \mathrm{a}$ \\
Indian & 0.9 & 1.1 & $\mathrm{n} / \mathrm{a}$ & $\mathrm{n} / \mathrm{a}$ & 0.9 & 1.0 & 1.5 & 1.5 & 1.2 & $\mathrm{n} / \mathrm{a}$ \\
Others & 10.6 & 6.0 & $\mathrm{n} / \mathrm{a}$ & $\mathrm{n} / \mathrm{a}$ & 0.4 & 0.3 & 1.0 & 0.9 & 0.4 & $\mathrm{n} / \mathrm{a}$ \\
Nominees & 2.1 & $\mathrm{n} / \mathrm{a}$ & $\mathrm{n} / \mathrm{a}$ & $\mathrm{n} / \mathrm{a}$ & 8.0 & 8.5 & 8.3 & 8.5 & 8.0 & $\mathrm{n} / \mathrm{a}$ \\
Foreign & 62.1 & 63.3 & 53.3 & 47.5 & 24.0 & 25.4 & 27.7 & 31.3 & 32.5 & 41.4 \\
Total & 100.0 & 100.0 & 100.0 & 100.0 & 100.0 & 100.0 & 100.0 & 100.0 & 100.0 & 100.0 \\
& & & & & & & & & & \\
\hline \hline
\end{tabular}

Sources:

Second Malaysia Plan, 1971-1975 (Malaysia, 1971, p. 40)

Third Malaysian Plan, 1976-1980 (Malaysia, 1976, p. 184)

Fourth Malaysian Plan, 1981-1985 (Malaysia, 1981, p. 61)

Sixth Malaysian Plan, 1990-1995 (Malaysia, 1990, p. 13)

Seventh Malaysian Plan, 1996-2000 (p.86)

Ninth Malaysian Plan, 2006-2010 (Malaysia, 2006, p. 356-57)

Tenth Malaysian Plan, 2011-2015 (Malaysia, 2011, p. 148) 
Table 1: Hofstede-Gray Framework (adopted from Haniffa \& Cooke, 2002)

The Interrelationship between Cultural Dimensions and Accounting Practices

\begin{tabular}{|c|c|c|c|}
\hline $\begin{array}{c}\text { Hofstede Cultural } \\
\text { Dimensions }\end{array}$ & Ethnic groups & Accounting value & Accounting practice \\
\hline & $\begin{array}{l}\text { Bumiputras } \\
\text { (Malays) }\end{array}$ & & \\
\hline Power distance & High & Low professional $^{12}$ & $\begin{array}{l}\text { Low compliance } \\
\text { with legal } \\
\text { requirements }\end{array}$ \\
\hline Masculinity & Low & High secrecy & Low disclosure \\
\hline Uncertainty avoidance & High & High uniformity & Less flexibility \\
\hline Individualism & Low & High conservatism & Less optimism \\
\hline Power distance & Chinese & High professional & $\begin{array}{l}\text { High compliance } \\
\text { with legal } \\
\text { requirements }\end{array}$ \\
\hline Masculinity & Low & Low secrecy & High disclosure \\
\hline Uncertainty avoidance & Low & Low uniformity & High flexibility \\
\hline Individualism & High $^{13}$ & Low conservatism & High optimism \\
\hline
\end{tabular}

12 Even though Gray (1988) hypothesises that a higher rank of professionalism is more likely when there are higher ranks of individualism and lower ranks of uncertainty avoidance and power distance, Haniffa and Cooke (2002) documents Chinese are more professional relative to Malays. Abdul Rashid and Ho (2003) further support this proposition by suggesting that Chinese dominates the business ethics in relationships with suppliers and other business partners in Malaysia.

${ }^{13}$ According to Hofstede (1991), Chinese rank low on individualism. However, the study by Haniffa and Cooke (2002) document that Chinese have relatively high ranking of individualism compared to the Malay groups. 
Table 2: Operational Definition of Variables

\begin{tabular}{|c|c|c|c|c|c|}
\hline \# & Variables & Sign & Definitions & Source(s) & \\
\hline \multicolumn{6}{|l|}{ Panel } \\
\hline $\begin{array}{l}\text { A:Depend } \\
\text { ent } \\
\text { Variable } \\
\quad 1\end{array}$ & $F E$ & - & $\begin{array}{l}\text { Forecast error defined as the } \\
\text { natural log transformation of } \\
\text { the absolute value of the } \\
\text { differences between actual } \\
\text { and median forecast scaled } \\
\text { by price }\end{array}$ & $\mathrm{I} / \mathrm{B} / \mathrm{E} / \mathrm{S}$ & \\
\hline \multicolumn{6}{|c|}{ Panel B: Independent Variables } \\
\hline 2 & BUMI & & \begin{tabular}{llll} 
Proportion of & \multicolumn{2}{c}{ Bumiputras } \\
directors & on & board & of \\
directors & & &
\end{tabular} & Hand collected & \\
\hline 3 & DUALITY & & $\begin{array}{l}\text { Takes the value of } 1 \text { if the } \\
\text { CEO separates from the } \\
\text { Chairman }\end{array}$ & Hand collected & \\
\hline 4 & BODIND & & $\begin{array}{l}\text { Percentage of independent } \\
\text { directors on board }\end{array}$ & Hand collected & \\
\hline 5 & BODSIZE & & $\begin{array}{l}\text { Natural log transformation of } \\
\text { total number of directors on } \\
\text { board }\end{array}$ & Hand collected & \\
\hline 6 & INSTOWN & & $\begin{array}{l}\% \text { ownership by top } 5 \\
\text { institutional investors }\end{array}$ & Hand collected & \\
\hline \multicolumn{6}{|c|}{ Panel C: Control Variables } \\
\hline 7 & MANOWN & & $\begin{array}{ll}\text { Direct } & \text { managerial } \\
\text { shareholdings } & \end{array}$ & Hand collected & \\
\hline 8 & LNNUMEST & & $\begin{array}{l}\text { Natural log transformation of } \\
\text { number of analysts following } \\
\text { a firm }\end{array}$ & $\mathrm{I} / \mathrm{B} / \mathrm{E} / \mathrm{S}$ & \\
\hline 9 & HORIZON & & $\begin{array}{l}\text { Natural log transformation of } \\
\text { number of days between the } \\
\text { forecast and actual } \\
\text { announcement of EPS }\end{array}$ & $\mathrm{I} / \mathrm{B} / \mathrm{E} / \mathrm{S}$ & \\
\hline 10 & MKTCAP* & & $\begin{array}{l}\text { Natural log transformation of } \\
\text { market capitalisation }\end{array}$ & $\begin{array}{l}\text { Compustat } \\
\text { missing data } \\
\text { collected. }\end{array}$ & $\begin{array}{r}\text { Global, } \\
\text { hand }\end{array}$ \\
\hline 11 & $B I G N$ & & $\begin{array}{l}\text { An indicator variable that } \\
\text { takes the value of } 1 \text { if the } \\
\text { auditor is a Big } 4 \text { auditor, } \\
\text { zero otherwise }\end{array}$ & $\begin{array}{l}\text { Compustat } \\
\text { missing data } \\
\text { collected }\end{array}$ & $\begin{array}{l}\text { Global, } \\
\text { hand }\end{array}$ \\
\hline \multirow[t]{2}{*}{12} & XLIST & & $\begin{array}{l}\text { Takes the value of I if the } \\
\text { firm is listed overseas }\end{array}$ & Hand collected & \\
\hline & STROA & & $\begin{array}{l}\text { Standard deviation of return } \\
\text { on assets (rolling for } 3 \text { years) }\end{array}$ & $\begin{array}{l}\text { Compustat } \\
\text { missing data } \\
\text { collected }\end{array}$ & $\begin{array}{r}\text { Global, } \\
\text { hand }\end{array}$ \\
\hline \multicolumn{6}{|c|}{ Panel D: Fixed Effects Variables } \\
\hline 13 & INDUSTRIES & & Industries dummies & $\begin{array}{l}\text { Compustat } \\
\text { missing data } \\
\text { collected }\end{array}$ & $\begin{array}{r}\text { Global, } \\
\text { hand }\end{array}$ \\
\hline 14 & PERIOD & & Year dummies & - & \\
\hline
\end{tabular}


Table 3: Industry Classifications (1999-2009, n=664)

\begin{tabular}{lcc}
\hline \hline & No of observations & $\%$ \\
\hline AGRICULTURE & 21 & 3.16 \\
CONSTRUCT & 125 & 18.83 \\
MANUFACTURING & 86 & 12.95 \\
CONSUMER & 198 & 29.82 \\
TRANSPORTATION & 56 & 8.43 \\
WHOLESALE & 47 & 7.08 \\
HEALTH & 15 & 2.26 \\
OTHERS & 92 & 13.86 \\
HOTEL & 24 & 3.61 \\
& & \\
Total & 664 & 100.00 \\
& & \\
\hline \hline
\end{tabular}


Table 4: Descriptive Analysis (1999-2009, $n=664)$

\begin{tabular}{|c|c|c|c|c|c|}
\hline & Mean & Median & Maximum & Minimum & Std. Dev. \\
\hline \multicolumn{6}{|c|}{ Panel A: Dependent Variable } \\
\hline$F E$ & -4.334 & -4.346 & 3.260 & -10.113 & 1.751 \\
\hline \multicolumn{6}{|c|}{ Panel B: Independent Variables } \\
\hline BODBUMI & 3.150 & 3.000 & 12.000 & 0.000 & 2.317 \\
\hline BUMI & 43.049 & 37.500 & 100.000 & 0.000 & 29.448 \\
\hline DUALITY & 0.686 & 1.000 & 1.000 & 0.000 & 0.465 \\
\hline BODIND & 36.257 & 33.333 & 85.714 & 0.000 & 16.265 \\
\hline BODSIZE & 7.266 & 7.000 & 17.000 & 3.000 & 2.059 \\
\hline LNBODSIZE & 1.944 & 1.946 & 2.833 & 1.099 & 0.278 \\
\hline INSTOWN & 17.035 & 11.499 & 94.371 & 0.000 & 18.627 \\
\hline \multicolumn{6}{|c|}{ Panel C: Control Variables } \\
\hline$M A N O W N$ & 5.218 & 0.191 & 70.755 & 0.000 & 12.302 \\
\hline NUMEST & 6.447 & 3.000 & 31.000 & 1.000 & 7.298 \\
\hline LNNUMEST & 1.220 & 1.099 & 3.434 & 0.000 & 1.148 \\
\hline HORIZON & 56.740 & 42.000 & 330.000 & 11.000 & 59.313 \\
\hline LNHORIZON & 3.745 & 3.738 & 5.799 & 2.398 & 0.697 \\
\hline МКТСАР & 1806342611.328 & 638396694.200 & 47008692268.000 & 12658180.000 & 3691550517.983 \\
\hline MKTCAP* & 20.367 & 20.274 & 24.574 & 16.354 & 1.336 \\
\hline$B I G N$ & 0.761 & 1.000 & 1.000 & 0.000 & 0.427 \\
\hline XLIST & 0.062 & 0.000 & 1.000 & 0.000 & 0.241 \\
\hline STROA & 4.997 & 3.827 & 41.971 & 0.000 & 4.666 \\
\hline
\end{tabular}

FE is natural log transformation of absolute forecast error scaled by share price. BODBUMI is the number of Bumiputra directors on board. BUMI is percentage of Bumiputra directors on board. DUALITY takes the value of 1 if the firm separates the CEO and Chairman functions. BODIND is the percentage of independent directors on board. BODSIZE is the total number of directors on board. LNBODSIZE is the natural log transformation of the total number of directors. INSTOWN is the percentage of top 5 institutional shareholders. MANOWN is direct managerial shareholdings. NUMEST is the number of analysts following a firm. LNNUMEST is the natural log transformation of NUMEST. HORIZON is the number of days between the forecast date and actual announcement of earnings while LNHORIZON is natural log transformation of HORIZON. MKTCAP is total market capitalisation and MKTCAP* is natural log transformation of MKTCAP. BIGN takes the value of 1 if the auditor is Big 4 auditor. XLIST takes the value 1 if the firm is cross listed overseas. STROA is the standard deviation of returns on assets. 
Table 5: Correlations (1999-2009, $n=664)$

\begin{tabular}{|c|c|c|c|c|c|c|c|c|c|c|c|c|c|}
\hline & $F E$ & BUMI & DUALITY & BODIND & BODSIZE & INSTOWN & MANOWN & LNNUMEST & HORIZON & MКТСАР & $B I G N$ & XLIST & STROA \\
\hline$F E$ & & $0.112 * * *$ & 0.006 & 0.038 & $0.081 * *$ & 0.028 & -0.016 & $-0.248^{* * *}$ & $0.146^{* * *}$ & $-0.160 * * *$ & -0.062 & 0.019 & -0.062 \\
\hline$B U M I$ & $0.111^{* * *}$ & & 0.008 & $0.168^{* * *}$ & 0.063 & $0.252 * * *$ & -0.029 & $0.088^{* *}$ & $-0.144 * * *$ & -0.016 & $-0.064 *$ & $-0.087^{* *}$ & -0.044 \\
\hline DUALITY & 0.007 & -0.003 & & -0.062 & 0.044 & 0.020 & $-0.150 * * *$ & 0.037 & -0.024 & -0.006 & $0.091 * *$ & $-0.096 * *$ & $-0.065^{*}$ \\
\hline BODIND & 0.044 & $0.171^{* * *}$ & $-0.071 *$ & & $-0.287 * * *$ & 0.050 & $-0.066^{*}$ & 0.025 & -0.023 & -0.013 & -0.026 & 0.006 & 0.022 \\
\hline BODSIZE & 0.061 & 0.023 & 0.059 & $-0.196 * * *$ & & $0.102 * * *$ & $0.142 * * *$ & $0.077^{* *}$ & $-0.145 * * *$ & $0.078 * *$ & $0.099 * *$ & 0.005 & $0.065^{*}$ \\
\hline INSTOWN & 0.044 & $0.269 * * *$ & $0.095 * *$ & $0.079 * *$ & $0.073^{*}$ & & $-0.116^{* * *}$ & $0.226^{* * *}$ & -0.040 & $0.216^{* * *}$ & $0.120 * * *$ & 0.048 & $-0.109 * * *$ \\
\hline MANOWN & -0.005 & -0.020 & $-0.077 * *$ & 0.053 & -0.008 & $-0.112^{* * *}$ & & $-0.133 * * *$ & $0.087 * *$ & $-0.299 * * *$ & $-0.110 * * *$ & -0.043 & $0.180^{* * *}$ \\
\hline LNNUMEST & $-0.238 * * *$ & $0.066^{*}$ & 0.031 & 0.021 & $0.097 * *$ & $0.153^{* * *}$ & $-0.187 * * *$ & & $-0.193 * * *$ & $0.588^{* * *}$ & $0.143^{* * *}$ & $0.083^{* *}$ & 0.007 \\
\hline HORIZON & $0.170^{* * *}$ & $-0.094 * *$ & -0.010 & -0.007 & $-0.116^{* * *}$ & -0.042 & $0.129 * * *$ & $-0.235^{* * *}$ & & $-0.112 * * *$ & -0.041 & -0.017 & $-0.090 * * *$ \\
\hline МКТСАР & $-0.179 * * *$ & -0.041 & 0.001 & 0.001 & $0.073 *$ & $0.211^{* * *}$ & $-0.271 * * *$ & $0.584^{* * *}$ & $-0.161 * * *$ & & $0.156^{* * *}$ & $0.127^{* * *}$ & $-0.111^{* * *}$ \\
\hline$B I G N$ & -0.052 & $-0.064^{*}$ & $0.091 * *$ & -0.015 & $0.119 * * *$ & $0.149 * * *$ & -0.051 & $0.150 * * *$ & -0.040 & $0.148 * * *$ & & $0.114^{* * *}$ & -0.014 \\
\hline XLLIST & 0.014 & $-0.099 * *$ & $-0.096 * *$ & 0.024 & 0.015 & $0.097 * *$ & -0.047 & $0.087 * *$ & -0.016 & $0.160 * * *$ & $0.114 * * *$ & & -0.007 \\
\hline STROA & -0.042 & $-0.079 * *$ & $-0.078 * *$ & -0.004 & 0.010 & $-0.100 * * *$ & $0.171^{* * *}$ & -0.038 & -0.050 & $-0.097 * *$ & -0.024 & -0.036 & \\
\hline
\end{tabular}

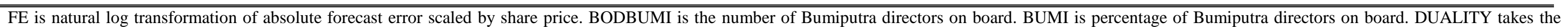

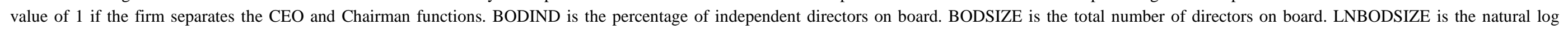

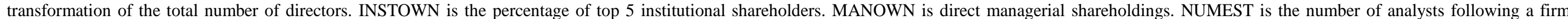

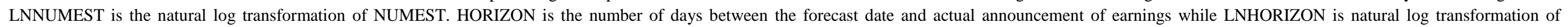

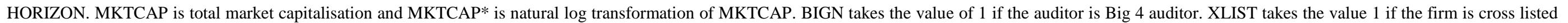
overseas. STROA is the standard deviation of returns on assets. 


\section{Table 6: Differences in Mean and Median between Bumiputras directors above and below the median value $(1999-2009, n=664)$}

\begin{tabular}{|c|c|c|c|c|c|c|}
\hline & $\begin{array}{c}\text { Bumi }<=3 \\
\text { Mean }\end{array}$ & $\begin{array}{l}\mathrm{n}=422 \\
\text { Median }\end{array}$ & $\begin{array}{c}\text { Bumi>3 } \\
\text { Mean }\end{array}$ & $\begin{array}{l}\mathrm{n}=242 \\
\text { Median }\end{array}$ & $\begin{array}{c}\text { t-test } \\
\text { (p-value) }\end{array}$ & $\begin{array}{c}\text { Mann- } \\
\text { Whitney } \\
\text { (p-value) }\end{array}$ \\
\hline \multicolumn{7}{|c|}{ Panel A: Dependent Variable } \\
\hline$F E$ & -4.487 & -4.459 & -4.066 & -4.095 & 0.076 & 0.041 \\
\hline \multicolumn{7}{|c|}{ Panel B: Independent Variables } \\
\hline DUALITY & 0.681 & 1.000 & 0.694 & 1.000 & $(0.000)$ & \\
\hline BODIND & 34.645 & 33.333 & 39.074 & 37.500 & 0.327 & 0.592 \\
\hline BODSIZE & 6.832 & 7.000 & 8.025 & 8.000 & 0.000 & 0.000 \\
\hline LNBODSIZE & 1.889 & 1.946 & 2.041 & 2.079 & 0.000 & 0.000 \\
\hline INSTOWN & 12.385 & 7.866 & 25.162 & 18.168 & 0.000 & 0.000 \\
\hline LNNUMEST & 1.125 & 0.693 & 1.386 & 1.386 & 0.117 & 0.121 \\
\hline HORIZON & 60.513 & 43.000 & 50.145 & 38.000 & 0.765 & 0.002 \\
\hline LNHORIZON & 3.802 & 3.761 & 3.646 & 3.638 & 0.068 & 0.002 \\
\hline МКТСАР & 1989495576.210 & 617086527.400 & 1486203338.000 & 710392500.000 & 0.006 & 0.000 \\
\hline MKTCAP* & 20.341 & 20.241 & 20.411 & 20.381 & 0.000 & 0.000 \\
\hline$B I G N$ & 0.747 & 1.000 & 0.785 & 1.000 & $(0.279)$ & \\
\hline XLIST & 0.069 & 0.000 & 0.050 & 0.000 & $(0.674)$ & \\
\hline STROA & 5.467 & 4.210 & 4.175 & 3.156 & 0.030 & 0.101 \\
\hline
\end{tabular}

FE is natural log transformation of absolute forecast error scaled by share price. BODBUMI is the number of Bumiputra directors on board. BUMI is percentage of Bumiputra directors on board. DUALITY takes the value of 1 if the firm separates the CEO and Chairman functions. BODIND is the percentage of independent directors on board. BODSIZE is the total number of directors on board. LNBODSIZE is the natural log transformation of the total number of directors. INSTOWN is the percentage of top 5 institutional shareholders. MANOWN is direct managerial shareholdings. NUMEST is the number of analysts following a firm. LNNUMEST is the natural log transformation of NUMEST. HORIZON is the number of days between the forecast date and actual announcement of earnings while LNHORIZON is natural log transformation of HORIZON. MKTCAP is total market capitalisation and MKTCAP* is natural log transformation of MKTCAP. BIGN takes the value of 1 if the auditor is Big 4 auditor. XLIST takes the value 1 if the firm is cross listed overseas. STROA is the standard deviation of returns on assets. Chi-square $\left(\mathrm{X}^{2}\right)$ values are in parenthesis.(mana ya??) 
Table 7: Regressions Analysis (1999-2009, n=664)

\begin{tabular}{|c|c|c|c|c|c|c|c|}
\hline Variable & $\begin{array}{l}\text { Expected } \\
\text { Direction }\end{array}$ & $\begin{array}{c}\text { Coefficient } \\
1 \\
\end{array}$ & $\begin{array}{c}\text { Coefficient } \\
2 \\
\end{array}$ & $\begin{array}{c}\text { Coefficient } \\
3 \\
\end{array}$ & $\begin{array}{c}\text { Coefficient } \\
4 \\
\end{array}$ & $\begin{array}{c}\text { Coefficient } \\
5 \\
\end{array}$ & $\begin{array}{c}\text { Coefficient } \\
6 \\
\end{array}$ \\
\hline \multirow[t]{2}{*}{ INTERCEPT } & $?$ & -5.229 & -5.457 & -5.038 & -4.191 & -5.228 & -3.658 \\
\hline & & $-2.930 * * *$ & $-3.045 * * *$ & $-2.830 * * *$ & $-2.083 * *$ & $-2.927 * * *$ & $-1.802 *$ \\
\hline \multirow[t]{2}{*}{$B U M I$} & + & 0.008 & 0.012 & -0.001 & -0.010 & 0.009 & -0.027 \\
\hline & & $2.979 * * *$ & $2.595 * *$ & -0.197 & -0.578 & $2.391 * *$ & -1.357 \\
\hline \multirow[t]{2}{*}{ DUALITY } & - & 0.046 & 0.284 & 0.029 & 0.023 & 0.046 & 0.240 \\
\hline & & 0.286 & 1.007 & 0.182 & 0.142 & 0.285 & 0.857 \\
\hline \multirow[t]{2}{*}{ BODIND } & - & 0.005 & 0.006 & -0.004 & 0.005 & 0.005 & -0.006 \\
\hline & & 1.135 & 1.232 & -0.587 & 1.163 & 1.136 & -0.812 \\
\hline \multirow[t]{2}{*}{ LNBODSIZE } & ? & 0.895 & 0.927 & 0.962 & 0.425 & 0.894 & 0.299 \\
\hline & & $2.840 * * *$ & $2.934 * * *$ & $3.047 * * *$ & 0.793 & $2.831 * * *$ & 0.560 \\
\hline \multirow[t]{2}{*}{ INSTOWN } & - & 0.001 & 0.001 & 0.000 & 0.000 & 0.002 & 0.003 \\
\hline & & 0.186 & 0.265 & 0.101 & 0.052 & 0.184 & 0.333 \\
\hline \multirow[t]{2}{*}{ MANOWN } & + & -0.011 & -0.011 & -0.010 & -0.011 & -0.011 & -0.010 \\
\hline & & $-1.754 *$ & $-1.763^{*}$ & -1.604 & $-1.757^{*}$ & $-1.755 *$ & -1.591 \\
\hline \multirow[t]{2}{*}{ LNNUMEST } & - & -0.281 & -0.277 & -0.283 & -0.279 & -0.282 & -0.274 \\
\hline & & $-3.579 * * *$ & $-3.513 * * *$ & $-3.607 * * *$ & $-3.552 * * *$ & $-3.577 * * *$ & $-3.510 * * *$ \\
\hline \multirow[t]{2}{*}{ LNHORIZON } & + & 0.335 & 0.332 & 0.337 & 0.336 & 0.335 & 0.334 \\
\hline & & $3.495 * * *$ & $3.465 * * *$ & $3.508 * * *$ & $3.510 * * *$ & $3.488 * * *$ & $3.486 * * *$ \\
\hline \multirow[t]{2}{*}{ МКТСАР* } & - & -0.148 & -0.143 & -0.145 & -0.152 & -0.148 & -0.145 \\
\hline & & $-1.989 *$ & $-1.925 *$ & $-1.961 *$ & $-2.036^{* *}$ & $-1.989 *$ & $-1.963 *$ \\
\hline \multirow[t]{2}{*}{$B I G N$} & - & -0.018 & -0.035 & 0.004 & -0.034 & -0.016 & -0.027 \\
\hline & & -0.098 & -0.196 & 0.022 & -0.188 & -0.089 & -0.148 \\
\hline \multirow[t]{2}{*}{ XLIST } & - & 0.572 & 0.597 & 0.617 & 0.567 & 0.570 & 0.641 \\
\hline & & 1.573 & $1.642 *$ & $1.703 *$ & 1.562 & 1.564 & $1.771^{*}$ \\
\hline \multirow[t]{2}{*}{ STROA } & - & 0.005 & 0.005 & 0.004 & 0.005 & 0.005 & 0.006 \\
\hline & & 0.294 & 0.340 & 0.267 & 0.300 & 0.305 & 0.368 \\
\hline \multirow[t]{2}{*}{$B U M I * D U A L I T Y$} & $?$ & & -0.006 & & & & -0.006 \\
\hline & & & -0.999 & & & & -1.053 \\
\hline \multirow[t]{2}{*}{$B U M I * B O D I N D$} & $?$ & & & 0.000 & & & 0.000 \\
\hline & & & & $1.698 *$ & & & $2.066^{*}$ \\
\hline \multirow[t]{2}{*}{$B U M I * L N B O D S I Z E$} & ? & & & & 0.010 & & 0.015 \\
\hline & & & & & 1.067 & & 1.582 \\
\hline \multirow[t]{2}{*}{ BUMI*INSTOWN } & $?$ & & & & & 0.000 & 0.000 \\
\hline & & & & & & -0.101 & -0.419 \\
\hline Industry fixed & $?$ & Yes & Yes & Yes & Yes & Yes & Yes \\
\hline Period fixed & ? & Yes & Yes & Yes & Yes & Yes & Yes \\
\hline Adjusted $R^{2}$ & & 0.137 & 0.137 & 0.141 & 0.138 & 0.136 & 0.143 \\
\hline F-statistic & & $4.193 * * *$ & $4.107 * * *$ & $4.188 * * *$ & $4.114^{* * *}$ & $4.063^{* * *}$ & $3.978 * * *$ \\
\hline
\end{tabular}

FE is natural log transformation of absolute forecast error scaled by share price. BUMI is percentage of Bumiputra directors on board. DUALITY takes the value of 1 if the firm separates the CEO and Chairman functions. BODIND is the percentage of independent directors on board. BODSIZE is the total number of directors on board. LNBODSIZE is the natural log transformation of the total number of directors. INSTOWN is the percentage of top 5 institutional shareholders. MANOWN is direct managerial shareholdings. NUMEST is the number of analysts following a firm. LNNUMEST is the natural log transformation of NUMEST. LNHORIZON is natural $\log$ transformation of HORIZON. MKTCAP* is natural log transformation of MKTCAP. BIGN takes the value of 1 if the auditor is Big 4 auditor. XLIST takes the value 1 if the firm is cross listed overseas. STROA is the standard deviation of returns on assets. 